\title{
Most Significant Changes Experienced by Farmers from Adopting Rainforestation Farming
}

\author{
Genie Leen M. Velarde, Rotacio S. Gravoso, Editha G. Cagasan \\ and
} Christina A. Gabrillo

\author{
Visayas State University, Visca, Baybay City \\ Leyte, the Philippines
}

\begin{abstract}
The Visayas State University (VSU) developed the rainforestation farming (RF) system to replace the more destructive forms of kaingin or slash-and-burn practices commonly practiced by farmers and provide them with a stable and higher income. VSU disseminated the technology through training and establishment of demonstration farms coupled with various extension materials. The most important changes experienced by farmers from adopting RF were increase in income, greater social skills, improvement of their water and air conditions, and enhancement of biodiversity in their rainforestation farms.
\end{abstract}

Keywords: project impacts, technology adoption, tree farmers, participatory monitoring and evaluation, Leyte

\section{INTRODUCTION}

The Visayas State University developed the practice of rainforestation farming (RF) as a response to alarming environmental problems in the Philippine uplands. RF aims to replace the more destructive forms of kaingin or slash-and-burn practices, form a buffer zone around the primary forests, protect biodiversity, help maintain the water cycle of Leyte Island, and provide farmers with stable and higher incomes (Milan and Margraf 1994; Shulte 2003). Promoting the use of local tree species, RF works with the hypothesis that a farming system becomes increasingly sustainable as its physical structure and species composition become closer to the original local rainforest (Milan and Margraf 1994).

Since the development of RF, VSU, through its Tropical Ecology Program has disseminated the technology to farmers and policy-makers using various extension approaches. These included the establishment of demonstration farms and villagebased nurseries, production and distribution of communication materials, training courses, and exposure trips to RF demonstration farms. Realizing the technology's potential, the Philippine Department of Environment and Natural Resources (DENR) 
issued Memorandum Circular No. 2004-006 in August 2004, encouraging the integration of RF strategy in the development of forestland (Fernando 2005).

In Leyte, about 25 farmer associations or individual farmers have adopted the technology. As a result, two questions have arisen: 'Has adoption of the RF resulted in changes in the farmers' lives?' and 'If so, what are these changes?' This study was conducted to answer these questions.

Focusing only on three pioneering adopters - two farmers and one farmer association - this study aimed to determine the impacts of adopting RF. However, contrary to traditional methods for assessing impacts, the study did not apply quantitative approaches, but rather sought to find out what significant changes were achieved by adopting the technology. The decision to apply this technique is anchored in the belief that adopting RF causes a wide range of changes that may be difficult to capture using pre-identified quantitative performance indicators only. Thus, this study used a new participatory monitoring and evaluation (PM\&E) approach known as the most significant change (MSC) technique or the story approach.

Briefly, MSC involves the collection of significant change stories from the field and the systematic selection of most significant stories by panels of designated stakeholders (Davies 1998; Dart 1999). According to Davies and Dart (2005), this approach is appropriate when program implementers are interested in the effects of an intervention in people's lives and wish to include the words of non-professionals. Davies and Dart also argued that MSC is particularly useful in identifying unexpected changes or impacts of interventions, in helping stakeholders to pay attention to events valued by the clientele, and to help realign efforts towards achieving more of the 'wonderful things' and less 'terrible things'.

MSC has been applied in monitoring the effects of development projects (e.g. Dart 2000; Dart et al. 2000) and in a school reform context (Le Cornu et al. 2003). Experiences in these projects confirm the effectiveness of the technique in determining impacts and as a guide in adjusting project activities.

\section{RESEARCH METHOD}

The study was conducted in the three villages in Baybay City in Leyte Province, where RF farmer-adopters reside. Located in the mid-western part of the province, Baybay City has a total land area of 46,050 ha, $56.5 \%$ of which is devoted to agriculture. Farming, fishing and forestry are three of the most important economic activities in the municipality. The main crops grown are coconuts, rice, corn, bananas and abaca. The municipality is generally mountainous in the east and slopes down more gradually towards the western the shoreline. Baybay City in the south of the province is $116 \mathrm{~km}$ from the provincial capital (Tacloban City) in the north. From the 92 barangays, Barangays Marcos, Mailhi and Sitio Cienda in Barangay Gabas were chosen as the study sites (Figure 1). 


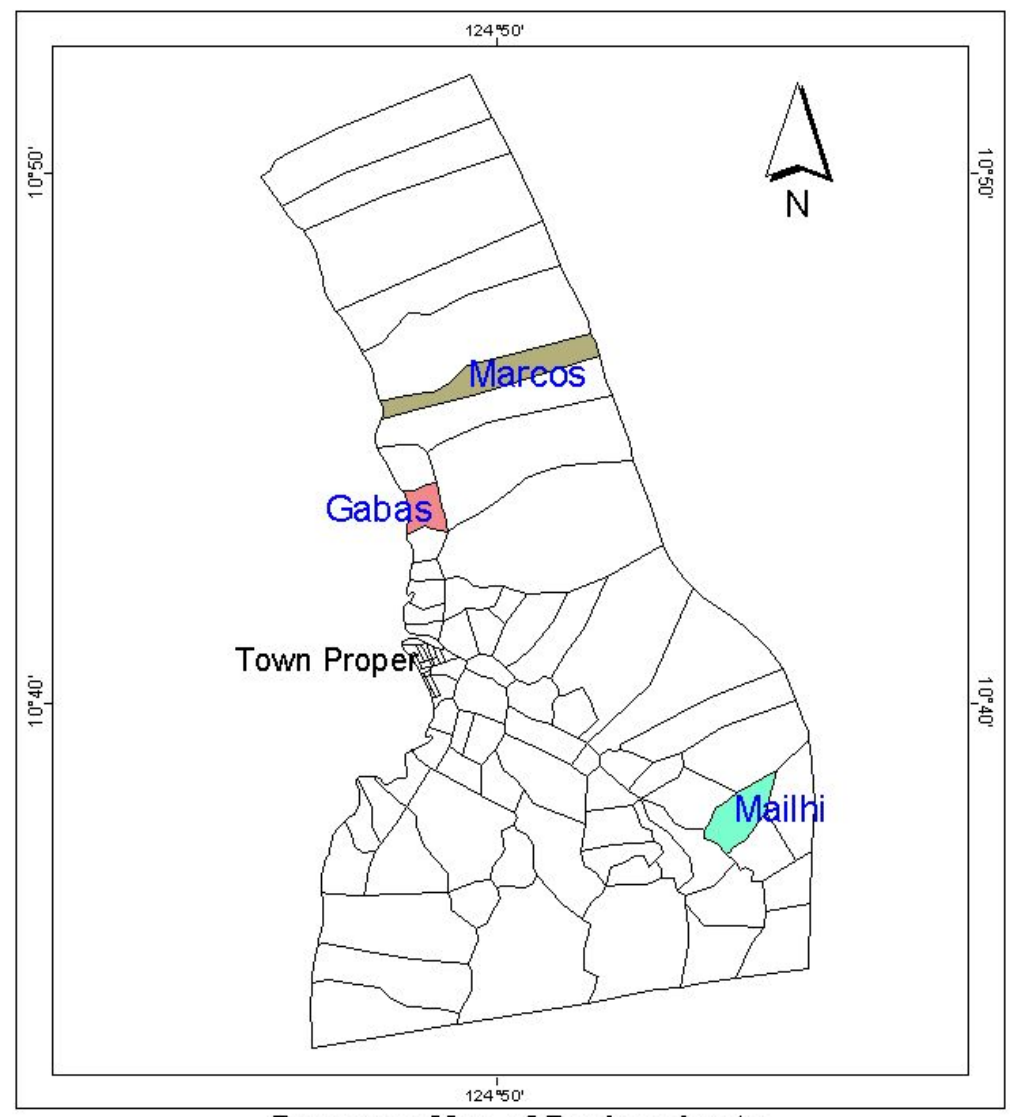

Barangay Map of Baybay, Leyte
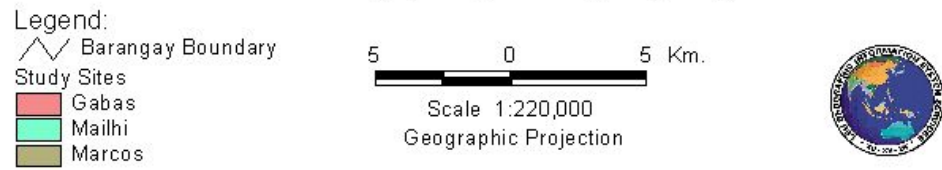

Map Source: DA-BAR

Prepared by: LSU GIS Services Unit, 2007

Figure 1. Map of Baybay City showing the study villages

\section{Research Design}

This study aimed to explore the main changes farmers have experienced from adopting the RF technology. The breadth and nature of the problem required intensive interviewing and observation, making it impractical to cover a larger sample. Thus, a case study design was used. According to Yin (2002), a case study is an inquiry that 
investigates a phenomenon occurring within its real-life context. A case study research is well suited in studies that focus on the effects of technology adoption.

This study utilized multiple data collection methods. These included key informant interviewing, in-depth interviews with the farmer-adopters, and review of documents of the then ViSCA-GTZ ${ }^{1}$ Applied Tropical Ecology Program (ATEP).

\section{Determining Impacts of RF Adoption}

The MSC technique was used to identify changes or impacts of RF adoption. A variation of the procedure discussed by Davies and Dart (2005) was employed, which is illustrated in Figure 2.

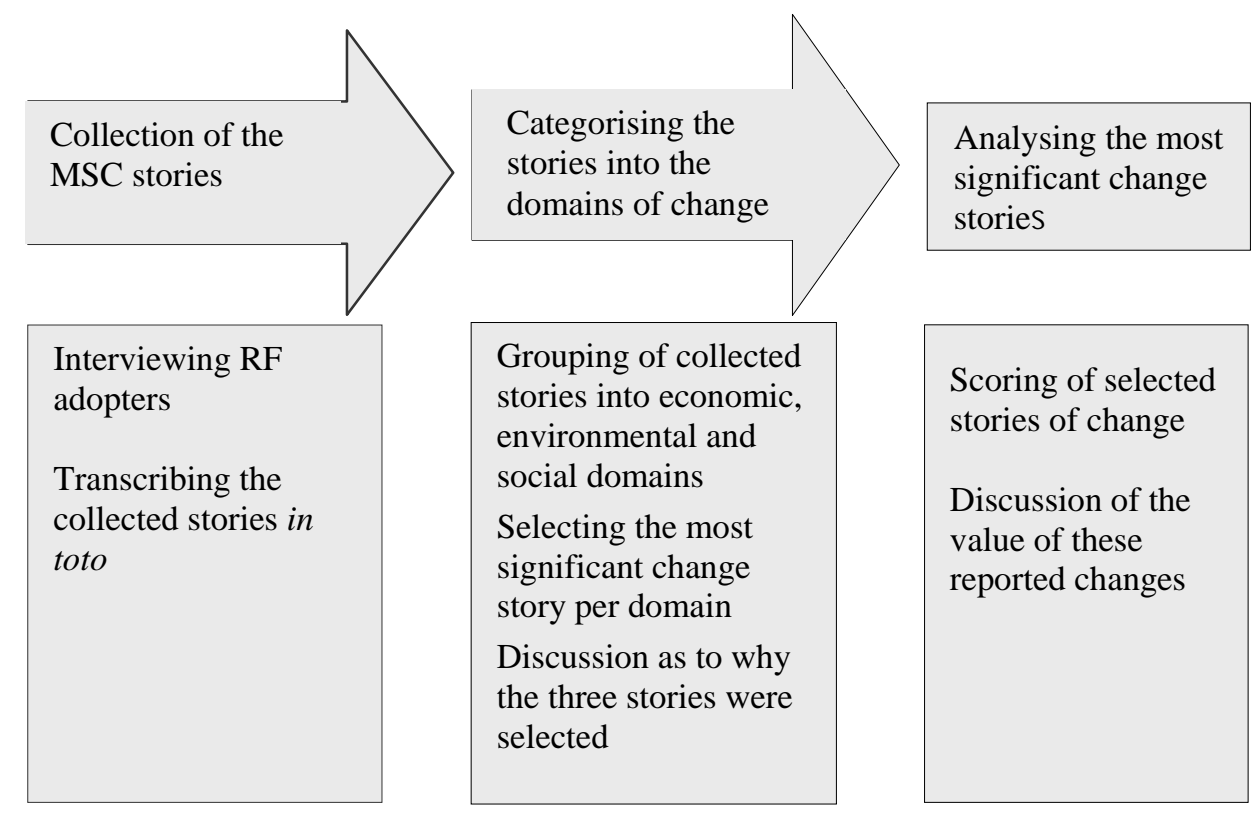

Figure 2. The MSC process adopted by this study

\section{Collecting the stories}

To gather information, farmers were asked to tell their stories about the changes they had experienced after adopting RF. These changes may be in terms in the productivity of their farm, environmental conditions, or changes in their socioeconomic conditions. Prior to collecting their stories, farmers were asked to sign an

1 ViSCA is an earlier name for Visayas State University, and GTZ is Deutsche Gessellschaft Fur Technische Zummanerbeit (German Agency for Technical Cooperation). 
informed consent indicating their permission to share their information. To guide them in telling their stories, the following key questions were asked: 1) 'What is the story?', (2) 'Where did this happen?', (3) 'When did it happen?', (4) 'What happened?', (5) 'What do you think is the significant change?' and (6) 'What difference has it made or will it make in the future?'. Their answers were recorded using a camcorder ${ }^{2}$ and then transcribed in toto. A total of 31 stories were collected, from 31 individual farmeradopters and members of the Cienda-San Vicente Farmers’ Association (CSVFA) and the Himbatuan Farmer's Association (HIFA), an organization trained in RF by CSVFA.

Categorising the stories into the domains of change

After transcribing the stories, two staff members of the Institute of Tropical Ecology (ITE), a unit at VSU implementing projects to promote RF, read and categorized the stories into economic, environmental and social changes. None of these types of change were defined precisely. According to Dart and Davies (2005), domains of change are not precisely defined, but are deliberately left loose; it is initially up to the field staff to interpret change belonging to any one of the categories.

After reviewing all the stories, the two ITE staff unanimously selected three stories that represented the most significant change from each domain. These three significant change stories were selected before asking a question that led to a discussion as to why the story was considered as the 'most significant' indicator of change in every domain. The ITE staff explained their criteria in story selection orally. These criteria were not decided on in advance but emerged through discussions of reported changes. The reasons as to why each story was selected were attached to the story.

Analysing the most significant stories in each category

A panel of key influencers was formed, composed of the ITE director and leaders of the project on RF. In a separate meeting, the three significant change stories chosen by the ITE staff along with the reasons for selection were shown to the panel of key influencers. The panel scored each story on a 10-point scale (with 10 as the highest score). The video footages of the farmers were shown to aid them in their scoring. As well as scoring, the panellists were asked to state their reasons as to why they chose a particular story for that domain.

\section{RESULTS AND DISCUSSION}

\section{Profile of the Farmer-Adopters}

Profiles were obtained from the three adopters whose stories were selected.

\footnotetext{
${ }^{2}$ Permission for video-taping was obtained from the farmers. However, it was stressed that the only purpose for using the recorder was to record their story.
} 
Adopter A:

Nong Macario Romano (Nong Macario), 67 years old, lives with his wife in a native house adjacent to his son's concrete house along the road in Brgy. Mailhi, a mountainous village in Baybay City, Leyte. The couple have five children, four of whom are boys. Nong Macario's rainforestation farm is on a 3.2 ha lot situated in a mountainous area, near the national highway. Aside from being a farmer, Nong Macario serves as a Brgy. Kagawad (village councillor) and is a member of Mailhi Agroforestry Association (MAFO). As a farmer, he earns approximately PhP10,000/month from sale of coconuts and other food crops. He is a Roman Catholic and claims to have no special beliefs, norms or traditions concerning trees.

Adopter B:

Manuel Posas (Sir Maning to many), an assistant professor teaching Agronomy courses at VSU, doubles as a farmer. Having taught for 32 years now, Sir Maning receives a monthly salary of $\mathrm{PhP} 18,000$, and has an income of more than $\mathrm{PhP} 10,000 /$ month from his farm. Sir Maning owns a 0.3 ha rainforestation farm in Brgy. Marcos, located about $1 \mathrm{~km}$ from his house across the national highway leading to Ormoc in the north. At the time of the study, he reported that two of his neighbours were starting to apply RF methods, and were staking their field before planting. Sir Maning's farm is characterized as hilly land. Adjacent to his farm is the rainforestation farm owned by his cousin. Sir Maning does not have special beliefs or traditions concerning trees.

Adopter C:

CSVFA is a people's organization based in the sitios of Cienda and San Vicente in Brgy. Gabas and Kilim. Organized in 1996 through the then ViSCA-GTZ ATEP, CSVFA was awarded by the Department of Environment and Natural Resources (DENR) with a Community-Based Forest Management Agreement covering a 2236 ha area. Under CBFMA, CSVFA are able to develop, use, and manage the 2236 ha area for 25 years. Led by a Board of Directors (BOD), CSVFA has admitted youth members to ensure sustainability of their forest.

Most of the members are involved in managing their $9707 \mathrm{~m}^{2} \mathrm{RF}$ farm located in Sitio Cienda. To get to the farm, one has to cross the shallow river locally known as Boyhang, ricefields and a hill, which at the time of the study was planted with sweet potatoes (Ipomoea batatas). At the top of the hill, a short trail that cuts across thick growth of cogon and talahib has to be trekked. On the farm, a signboard with CSVFA's name and collaborating agencies including the European Nature Heritage Fund (EURONATUR), is displayed.

\section{Reasons for Using the RF technology}

The 31 stories collected reveal a number of reasons for adopting RF, described as follows: 
Economic purposes. Farmer-adopters said that they adopted RF to earn additional income. Alfredo, a HIFA member, said that RF can be a revenue-generating business in the future, with trees being cut and sold for lumber. Alfredo's reason coincides with that of Nong Pidong, the current chairman of CSVFA. He added that, since their trees are registered with DENR, they can cut and sell them as lumber. Further, Nong Pidong reported that adoption of the rainforestation farming technology increases their income.

In the case of Nong Macario, he believed that trees in his rainforestation farm will be a source of money in the future. Sir Maning, on the other hand, reported that one of the reasons why he adopted RF was to earn an income from the fruit trees while his family can also eat the produce of his fruit trees.

Security of their children. All respondents believed that it takes about 10-15 years before trees can be harvested. However, they still adopted RF technology because they believe that their children and grandchildren will benefit greatly from their work. Nong Macario said that his rainforestation farm will serve as a legacy that he can pass on to his children. CSVFA members adopted the technology because they wanted their children to follow what they are doing to protect their watershed and forest. Moreover, they wanted their children to be able to see animals of various species and trees live in the forest and not just in picture books.

Improvement of air quality. CSVFA members including Nong Doming and Nong Toting reported that before adopting RF, they had noticed that the air in their locality had been getting warmer and drier. They therefore adopted RF to 'freshen the air'. According to them, they did not want to catch any disease due to air pollution. Nong Macario's reason for adoption was related to the CSVFA's reasons. He felt the air quality is a problem in Brgy. Mailhi, Baybay, and planted trees using the RF technology to improve air quality.

Adoption for watershed protection. Most of the CSVFA members reported that the need to protect their watershed motivated them to adopt RF. They commented that their water supply has declined significantly, and that during the dry season the river level drops abruptly. Most CSVFA members wanted to protect their watershed and maintain the water flow. According to them, the watershed supplies water to the town proper of Baybay area and the neighbouring villages.

Nong Macario reported a reduction in the river level a few metres from his house. He adopted RF in the hope of helping solve the water problem in his barangay.

Biodiversity conservation. Nong Pidong, the CSVFA president, said that one of the reasons why he adopted RF was to conserve biodiversity, which greatly benefits not only his own family but also other people.

To improve on-farm practice. According to Joseph, a CSVFA youth member, the association adopted RF because they observed that the exotic tree species previously planted on their farm did not grow well. They believed that through RF, site-species matching can be achieved on their farm. 
Reduction in landslides in the area. CSVFA members Tom-Tom and Nong Toting were aware that tree planting activities can reduce soil erosion. The CSVFA adopted $\mathrm{RF}$ to reduce occurrence and severity of landslides in their forest and mountains.

Access to fuelwood. Alfredo Bandalan, a member of the HIFA, a farmerorganization affiliated with CSVFA, reported that he used RF to supply firewood for family consumption. Since Nong Alfredo could not afford to buy liquified petroleum gas (LPG), he prefered to use dead branches of trees as firewood for home use.

\section{Problems Encountered by Farmer-Adopters}

A decade after first adopting the RF technology, there had been a number of farmrelated problems faced by the adopters. Farmers in the CSVFA observed that some forest trees on their RF farm died due to attacks of ground termites (Agathis philippinensis), a problem which they had reported to the ITE. Another problem faced by the association was continued illegal logging in their area. They also observed that the DENR personnel did not take seriously their requests to investigate illegal logging in their area.

Nong Macario said that the only problem he had with RF is associated with natural disasters such as storms. Whenever strong storms occurred, some of his trees were destroyed. However, now that his trees were getting bigger, this problem was less serious. He also observed that typhoons have been frequent in recent years. On the other hand, because Sir Maning worked on his own, his primary concern now was the tree pruning activities to be conducted on his farm every summer.

Whenever RF adopters experienced problems, they wanted to ask help from experts. In the case of ground termite attacks at Cienda, farmers said that they would like to consult an entomologist about the problem. However, so as not to undermine the efforts of the RF project organizers, they would like to discuss the problems with them first and also seek advice from them.

\section{Effects of Adopting RF}

One of the objectives of the study was to investigate impacts of adopting RF, using the MSC technique. Effects of adopting RF reported by respondents are summarized in Table 2.

Change in farmer-adopters' social skills. RF adopters claimed that improvement in social skills is one of the significant changes brought about by their adoption of RF. As stated in the memorandum of agreement, RF cooperators had to entertain visitors to their farms who were interested in the technology. The farmers valued this change because they believed that they gained confidence due to the many interactions they had with various kinds of people. Despite their inability to speak English (because most of them had only elementary schooling), they were now confident to face their visitors whether they are local, national or foreign visitors. 
Table 2. Some statements of adopters of impacts of adopting RF

\begin{tabular}{|c|c|}
\hline Perceived effect & Typical explanations given by farmers \\
\hline $\begin{array}{l}\text { Changes in } \\
\text { farmer-adopters' } \\
\text { personality }\end{array}$ & $\begin{array}{l}\text { 'Believe it or not, before, when there were visitors, including } \\
\text { foreigners, I was afraid because I only finished elementary education. } \\
\text { Now, whenever visitors pass by I already talk to them in English and } \\
\text { I am also prepared to meet them. It seems that my personality has } \\
\text { changed' (Renato Poliquit, CSVFA). }\end{array}$ \\
\hline $\begin{array}{l}\text { Change in } \\
\text { people's attitude } \\
\text { towards trees }\end{array}$ & $\begin{array}{l}\text { 'People's attitude has changed. They learned to love trees. Most of us } \\
\text { are disciplined now. To date, they no longer cut trees unless they ask } \\
\text { permission from our association' (Joseph Maceda, CSVFA youth } \\
\text { member). }\end{array}$ \\
\hline $\begin{array}{l}\text { Change in } \\
\text { members' } \\
\text { working } \\
\text { relationships }\end{array}$ & $\begin{array}{l}\text { 'Before, when there were no activities yet, we residents of Cienda } \\
\text { were not that close. When we started our activities, we got closer. } \\
\text { They were socialized' (Joel Polea, CSVFA youth member). }\end{array}$ \\
\hline $\begin{array}{l}\text { Improvement of } \\
\text { eco-tourism }\end{array}$ & $\begin{array}{l}\text { 'Before no one visited us. However, when we organized, whenever } \\
\text { ATEP had visitors, they were toured here' (Joel Polea, CSVFA youth } \\
\text { member). }\end{array}$ \\
\hline $\begin{array}{l}\text { Improvement in } \\
\text { farmers' income }\end{array}$ & $\begin{array}{l}\text { 'From the proceeds of the seedlings, we were able to buy a multicab } \\
\text { in year } 2000 \text {. Actually, it's a secondhand multicab owned by Gundi, a } \\
\text { German. Like what I said, we had a contract with Del Monte, in } \\
\text { Bukidnon, Philippines. Every time we deliver, we get about PhP } \\
80,000 \text {. They ordered around 30,000 seedlings sold at PhP15 each' } \\
\text { (Renato B. Poliquit, CSVFA member). }\end{array}$ \\
\hline $\begin{array}{l}\text { Improvement in } \\
\text { water condition }\end{array}$ & $\begin{array}{l}\text { 'The trees we planted there served as prevention against soil erosion. } \\
\text { Trees also minimized floods. Before, whenever there was rain, we } \\
\text { were flooded here. So, we were not able to go to school. Now, even if } \\
\text { it floods, it's not that strong and we can still go to school' (Joel } \\
\text { Polea, CSVFA youth member). }\end{array}$ \\
\hline $\begin{array}{l}\text { Improvement in } \\
\text { biodiversity }\end{array}$ & $\begin{array}{l}\text { 'Maybe one of the effects of RF was the bringing back of the } \\
\text { biodiversity. Based on my personal observation, we have Tarsius } \\
\text { herycta, locally known as 'Mago' in our farms. With the RF, we } \\
\text { could now see flying bats' (Joseph Maceda, CSVFA youth member). }\end{array}$ \\
\hline
\end{tabular}

Change in attitudes towards trees. After RF adoption, it became evident that there was a change in attitude towards trees, and their importance and benefits. Because of the many RF seminars attended by the farmer-adopters, their knowledge about trees improved. Moreover, some people in Sitio Cienda and San Vicente learned to respect the CSVFA and regard them as forest wardens. As a result, people were afraid to cut trees in the forest area without asking permission from the association. 
Change in members' working relationships. In the case of CSVFA, relationships among members were strengthened because of the many RF-related activities that they performed together. As one farmer put it, there was already cooperation among members of the CSVFA. If one member was in need, other members helped out.

Improvement of eco-tourism. Eco-tourism has flourished in the areas where demonstration farms are situated. Previously, these areas did not receive visitors, but following the adoption of RF and the establishment of demonstration farms, many local, national and foreign visitors now come to the barangay where the demonstration farms are located.

Increase in farmers' incomes. According to the farmer-adopters, the RF technology has contributed to their incomes. The additional income may be from their on-farm practices such as production of fruit, lumber and other food crops, and also seedling production. They considered this a result of adopting RF because they would not have ventured into seedling production had they not adopted RF.

Improvement in water quality. Thirteen years after adopting RF, the farmers interviewed were experiencing the ecological impacts brought about by the RF technology, including improvement in the water condition of their respective RFs. They valued this change for its ecological benefits.

Improvement in biodiversity. Before farmers adopted RF, they had been told that many animals and plants were in danger of becoming extinct. A decade after adopting the RF technology, all farmers across the three selected sites confirmed that native animals are now appearing on their farms. To the farmers, this is an important change as they felt that they had saved the lives of these animals.

\section{Most Significant Effects of Adopting RF}

From the 31 stories collected, the ITE staff were asked to choose stories they felt reflective of the kind of changes or effects they considered to be of significance. These stories were classified under economic, social and environmental domains of change.

Economic change: The story told by Renato Poliquit, CSVFA president, was selected as the most significant change under the economic category. The story was about the improved economic condition of the CSVFA because of the income gained from seedling production. The farmer also said that association established partnership with Del Monte Philippines ${ }^{3}$ for three years.

The panel chose the story because it mentioned the people's organization. According to them, the ITE organized groups of farmers, fishermen and other individuals before they formally established RF in their area. They felt that an organization in the village could help ensure sustainability of the RF. Furthermore, the

${ }^{3}$ Del Monte is a company that operates a pineapple plantation in Mindanao (the southern part of the Philippines) and is a major exporter of pineapple and pineapple products in the country. The company bought tree seedlings from CSVFA for its reforestation program. 
story was selected because, according to the panel, the CSVFA was able to construct a bunkhouse and buy a secondhand multicab from the income gained in seedling production. Some highlights of this story are:

'Our income increased because of the many ideas. Before, we only depended on our farm - rice farm, coconut farm, and abaca farm. Now that we were given a new technology like the RF, all I can say is that our income increased. However, other members who were lazy and who always wanted fun did not adopt RF. Thus, they always say that their income remains the same.'

'For me there is a big difference. Why? You receive something. That's a big difference. Next, my children can follow what I am doing. Now that they know the things I do, they will likely imitate. The things I am doing now are not for my own; it is for my children. Perhaps others did not adopt the technology because they depend on me (laughs).'

'We earned income from [the native tree] seedlings. So, we bought the multicab in year 2000. Like what I said, we had a contract with Del Monte, in Bukidnon, Philippines. They ordered around 30,000 seedlings sold at Php15 each. So, how much was that?'

'There is a big change because those who did not adopt are attracted to the technology now. They realized that, indeed, there is money in seedling production.'

Environmental change: Within the environmental domain, the ITE staff selected the story told by Sir Maning. The story describes the effects of RF technology on the condition of his farm. Specifically, he explained that his RF trees serve as windbreaks to other plants in the area, prevent soil erosion, improve soil quality and maintain the water cycle. He also added the effects of RF technology on biodiversity.

The panel members felt that this farmer understands the environmental effects of $\mathrm{RF}$ as he was able to describe the effects of the technology on the farm environment more holistically. They also believed that the specific changes narrated by the farmer in his story such as environmental protection, trees serving as windbreaks, presence of native animals, and soil fertility improvement were basically the changes RF wanted to attain.

The panel commented that the story was true. One panellist, who happened to live in the same barangay as this farmer, said that he was amazed at the changes on Sir Maning's farm. He confirmed these changes. This is part of Sir Maning's story:

'It has a big effect on the ecosystem. You can see a very good impact on the environment and the people in the community. In the ecology, I saw a number of insects and animals like birds. These animals existed in my farm before, but now, they are growing in number. The insects, spiders ... yes! You can see these animals on my farm. The Haribon Foundation documented the appearance of these species of animals every year'. 
'Also, I noticed that before, the air was dry and hot, now it's cool and fresh. Nowadays, I want to sleep in there (laughs). Before, cogon (Imperata cyclindrica) grew there. Now, I can see insects, birds, reptiles, millipedes and centipedes. I know that insects and animals are in my farm now'.

'It also offers environmental protection. For example, the trees served as windbreaks to other plants like the coconut. It is a source of water. Also, the trees help prevent soil erosion. If an area has no trees, it will likely experience landslides. That is one of the impacts of planting trees. At the same time, trees ... contribute to soil fertility improvement. The soil fertility is restored because of the leaf litter'.

Social change: Within the social domain, the ITE panel selected a story told by Nong Macario. Entitled Now, I'm confident!, the story is about how Nong Macario helped other people by sharing his knowledge and experiences gained as an RF farmer. Towards the end of the story, Nong Macario stresses that he does not mind even if he is committing much time in entertaining visitors. The ITE staff chose this story as an example of a farmer accepting his responsibilities as an RF cooperator as stipulated in the memorandum of agreement.

The panel of key influencers, however, pointed out that Nong Macario was now an RF educator and advocate in their community. His status had also improved as he had become the president of the Mailhi Forest Organization (MAFO) and was elected as the first barangay councillor. When the barangay captain died, Nong Macario took over. The panel also said that Nong Macario became more confident and friendly after he adopted RF. As a whole, the story was rated by the panel with an 8.3 score. In part, Nong Macario said:

'There is a difference. Especially now that my trees are growing big, I received a lot of visitors in my farm. Many people visited my place (laughs). Foreigners who were representatives from other countries like China, Japan came here. Most were Germans. I think it is expected because they helped us here. But [people from] neighbouring countries like Singapore and Thailand also visited my farm. There were a number of representatives from other countries alternately visiting my farm’.

\section{DISCUSSION}

This study determined the significant changes experienced by farmers after adopting the RF technology. As RF is now recommended as a strategy to rehabilitate degraded uplands, results of this study will prove useful to agencies mandated to spearhead the improvement of productivity of upland farmers.

Based on the testimonies of the farmer-adopters, they adopted RF because it was an appropriate response to their problems and because support services were available. 
A case in point was the recognized need of the farmers' association to prevent illegal logging while earning income. When they articulated their desire to take on the technology, technical and other support services were provided, and this encouraged rapid adoption.

Until now, ITE has relied mostly on interpersonal communication methods to disseminate RF. This is understandable considering that RF involves complex processes that require prospective adopters to see and try the steps for themselves. Only interpersonal communication could do this. However, now that a national campaign on RF has been instituted, ITE and its partner organizations should utilize the mass media. The reason is that, while extension - both through individual and group approaches - may be helpful, the fact that it is labour-intensive (Mody 1992) limits its effectiveness. According to Adhikarya (1994), the mass media, with its ability to reach large numbers of farmers who may be inaccessible to transportation, can make RF information widely available to farmers. Rogers (1995) observed that as the most rapid and efficient means to inform audiences, the mass media can reach millions of rural families in areas inaccessible by extension personnel. Should mass media be used, the messages may be designed to create awareness and motivate them to adopt RF and sustain its use.

Termite attack is one of the problems experienced by CSVFA in the use of RF. Unfortunately, no solution for this problem has been found during this study. It is therefore recommended that the problem be studied as soon as possible and appropriate recommendations be given. In future dissemination activities, it is suggested that control and prevention of termite attack be part of the RF package.

While the results of this study have answered some questions, findings have raised other questions that warrant follow-up studies. For example, this study focused only on the adopters. Thus, only the reasons for adoption have been documented. It will be interesting to find out what the other farmers' reasons are for not adopting the technology despite their awareness about it.

In this study, the MSC technique has proven to be useful tool for identifying changes brought about by rainforestation projects. As demonstrated in this study, the advantage of this technique is that, in contrast to conventional project monitoring and evaluation methods where criteria for success are imposed by the evaluators, the MSC allowed the project impacts to emerge from introspection by the adopters. The weakness inherent in the process is that it requires substantial time for data collection.

In this study, the use of a camcorder proved especially helpful. Most farmers, if not all, found it easy to tell their stories verbally. Likewise, project staff preferred to explain their criteria in story selection and give comments to the story verbally. Having to write down their stories can limit respondents' stories and ideas. Moreover, watching and listening directly to stories in the farmers' own words can add validity to the story.

Some stories of change told by the farmers were contradicted by other farmers. To address this problem, it is suggested that in gathering stories, farmers be brought 
together in a meeting and asked to generate their most significant stories. This process may be done effectively through a workshop.

Overall, the MSC technique showed potential for identifying project impacts. It is suggested that this technique be integrated into the project plan as part of project monitoring and evaluation activities.

\section{REFERENCES}

ADHIKARYA, R. 1994. Strategic Extension Campaign: A Participatory-oriented Method of Agricultural Extension. Food and Agriculture Organisation, Rome.

DART, J.J. 1999. A story approach for monitoring change in an agricultural extension project. Proceedings of the Association for Qualitative Research (AQR), International Conference, Melbourne. www.latrobe.edu.au/www/aqr/offer/papers/ JDart.htm. Accessed 16 May 2006.

DART, J.J. 2000. Stories for Change: A New Model of Evaluation for Agricultural Extension Projects in Australia. Institute of Land and Food Resources, University of Melbourne, Australia.

DART, J.J., G. DRYSDALE, D. COLE, and M. SADDINGTON. 2000. The Most Significant Change Approach for Monitoring an Australian Extension Project. International Institute for Environment and Development, London.

DAVIES, R. 1998. Order and Diversity: Representing and Assisting Organizational Learning in Non-Government Aid Organizations. PhD Thesis. University of Wales - Swansea. http://www.mande.co.uk/thesis,htm. Accessed 16 May 2006.

DAVIES, R. and J. DART. 2005. The Most Significant Change (MSC) Technique. A Guide to its Use. www.mande.co.uk/docs/MSCGuide.htm. Accessed 16 May 2006.

FERNANDO, E.S. 2005. Restoring the Philippine rainforests for biodiversity conservation, environmental protection, livelihood security and of the local people. Haribon Policy Paper No. 2, Manila.

LE CORNU, R., J. PETERS, M. FOSTER, R. BARRAT, R. and J. STRATFOLD. 2003. Exploring perceptions of 'significant change' in reforming school cultures in South Australia. International Journal of Knowledge, Culture and Change Management. 6(5): $161-70$.

MILAN, P.P. and J. MARGRAF. 1994. Rainforestation farming: An alternative to conventional concepts. Annals of Tropical Research. Special Issue on Tropical Ecology. 16(4): 17-26.

MODY, B. 1992. Talking to development bankers: Extension workers speak up. Development Communication Report. 79: 7-9.

ROGERS, E.V. 1995. Diffusion of innovations. Free Press, New York.

SHULTE, A. 2003. Rainforestation farming: Option for rural development and biodiversity conservation in the humid tropics of Southeast Asia. Volkmar Stiebitz, Congress Report GmBH. Shaker Verlag, Germany.

YIN, R.K. 2002. Case Study Research: Design and Methods. Sage Publications, Thousand Oaks, California. 